\title{
HSPA2 Expression Predicts Early Postsurgical Relapse and Promotes Tumor Cell Migration and Invasion in Pancreatic Cancer
}

\section{Research}

Keywords:

Posted Date: May 13th, 2021

DOI: https://doi.org/10.21203/rs.3.rs-218267/v3

License: (c) (1) This work is licensed under a Creative Commons Attribution 4.0 International License. Read Full License 


\section{Abstract}

The authors have requested that this preprint be withdrawn due to erroneous posting.

\section{Full Text}

The authors have withdrawn this preprint from Research Square. 